\title{
ACCEPTANCE OF VARIOUS WELDING TECHNIQUES FOR DISSIMILAR
}

\section{METALS}

\author{
SYED AQIB ALI ${ }^{1} \&$ RAVINDRA KUMAR ${ }^{2}$ \\ ${ }^{I}$ M.Tech Scholar, S.R.M.S Cet Bareilly Aktu, University, Uttar Pradesh, India \\ ${ }^{2}$ HOD, Mechanical Department, S.R.M.S Cet Bareilly, Aktu, University, Uttar Pradesh, India
}

\begin{abstract}
Now a day, dissimilar metal welding techniques has getting an increased attention by various industries. Different metal welding technologies in contemporary sectors, including automotive, aircraft, chemical plants and electronic components, place restrictive requirements on manufacturing methods and performance standards, and manufacture uses procedures of high quality and effectiveness that differ from metal welding to welding. Dissimilar metal welding can be the combination of two distinct alloys, the combination of one alloy with another filler metal, or the overlay of an alloy on a substratum for enhanced results. It will serve an essential role in the production of automobiles, aircraft, chemical plants and electronic components, leading in the use of significantly different metal welding techniques being given greater importance. In this research paper, researchers investigate techniques for dissimilar metal welding to be regarded in greater depth, variables or factors for dissimilar welding, and explore the sectors in which these techniques can be found.

KEYWORDS: Automobile; Chemical Plants; Contemporary Sector; Dissimilar Metal Welding; Performance Standards
\end{abstract}

Received: Jun 05, 2020; Accepted: Jun 25, 2020; Published: Jul 06, 2020; Paper Id.: IJMPERDJUN2020220

\section{INTRODUCTION}

Compared to existing laser welding, dissimilar metal welding is the combination of two different metals that wouldn't normally weld together because they have distinct chemical and mechanical characteristics and come from distinct alloy structures. It is worth noting that in what is still the significantly different metal welding process; two metals that appear the same and may even have the same name can be combined. They are still terribly different in nature if their key characteristics are distinct but they share the same name. A few of the newer, more specialized welding methods like laser, electron beam or friction welding are useful but not appropriate for all circumstances and are not regularly accessible to everyone. This manual will focus on prevalent procedures of fusion welding. The purpose of a dissimilar weld is to finish a joint with a filler metal to produce a sustained ductile weld with properties to meet the performance requirements.

This paper is structured in following manner. Section 2 gives a detailed study of various factors affecting the dissimilar metal welding. Section 3 provides the uses of dissimilar welding in various industries. Section 4 provides a comparative analyses of various techniques used for dissimilar welding of metals. Sections 5 conclude the paper and propose some future scope for further research exploration.

\subsection{Factors Affecting Dissimilar Metal Welding}

Before trying to join two distinct metals, it is essential to consider multiple variables, as this will not only evaluate how effective the welding will be, but also how long your freshly joined parts will probably last. The factors are 
discussed and mentioned in the table given below:-

Table 1: Factors Affecting Dissimilar Metal Welding [1]

\begin{tabular}{|c|c|l|}
\hline S. No & Factors & \multicolumn{1}{c|}{ Explanation } \\
\hline 1. & Solubility & $\begin{array}{l}\text { The solubility of the two significantly different materials which is the chemical } \\
\text { characteristics of a substance determining its capacity to dissolve in a solvent must be } \\
\text { mutual. The welding process will fail if the metals cannot be absorbed together. }\end{array}$ \\
\hline 2. & $\begin{array}{c}\text { Inter } \\
\text { metallic } \\
\text { compound }\end{array}$ & $\begin{array}{l}\text { Adequate study must be carried out on the inter metallic compounds that will form between } \\
\text { the two metals within the intersection area, researching stuff like crack tolerance, how prone } \\
\text { they are to corrosion, and their ductile capacity. }\end{array}$ \\
\hline 3. & $\begin{array}{c}\text { Weld } \\
\text { ability }\end{array}$ & $\begin{array}{l}\text { The weld ability level, which incorporates solubility and inter metallic compounds, relates } \\
\text { to the capacity of the two metals concerned to be welded effectively without generally } \\
\text { results in cracks or other negativity. This will differ between metal and metal. }\end{array}$ \\
\hline 4. & $\begin{array}{l}\text { Thermal } \\
\text { expansion } \\
\text { which is related to how the metals will structure in reaction to temperature variations. If } \\
\text { these are too distinct, the inner residual tensions of the two metals, which are the stresses } \\
\text { current after all the external influences have been withdrawn, will be much higher, which } \\
\text { can significantly decrease the residual stress of working life of welded metals. }\end{array}$ \\
\hline 5. & $\begin{array}{c}\text { Melting } \\
\text { rates }\end{array}$ & $\begin{array}{l}\text { As the two significantly different alloys may have distinct thermal conduction rates, they } \\
\text { may also have distinct melting rates, causing the two alloys to have an instant issue. }\end{array}$ \\
\hline 7. & $\begin{array}{l}\text { End- } \\
\text { service } \\
\text { conditions }\end{array}$ & $\begin{array}{l}\text { Corrosion may happen between the two significantly different metals ' transition region. If } \\
\text { the two metals are on wildly distinct parts of the electrochemical scale, this indicates a } \\
\text { elevated amount of corrosion vulnerability, which is a harmful issue for the fresh weld, of } \\
\text { course. }\end{array}$ \\
\hline $\begin{array}{l}\text { Finally, as well as correctly investigating and assessing the various chemical and } \\
\text { mechanical draw-ups of the dissimilar metals you are using, and how well they can be } \\
\text { susceptible for your dissimilar metals. }\end{array}$ \\
\hline
\end{tabular}

\subsection{Problems Faced in Dissimilar Metal Welding}

Key factors to be considered before choosing an appropriate welding technique for joining dissimilar products include elements such as the structure (if used) of dissimilar raw materials and filler material, service requirements, and joint design. The joint geometry makes it hard to apply certain welding techniques, e.g. friction welding. In welding significantly different metal joints, the primary causes of problems and implications are [1]:-

- Textural gradients and micro structural mismatch between significantly different base metals ending in big variability in the joint's chemical, physical, and mechanical characteristics, arising in brittle IMC creation.

- Issues related to welding comparable base metals on an individual basis.

- Enhanced joint difficulty due to the addition of materials for filling or insertion.

- Mismatch owing to significant variations in physical attributes such as temperature melting, thickness, thermal conductivity and rate of change of thermal expansion.

\subsection{Use of Dissimilar Metal Welding Techniques}

As pointed out in this paper, all metals have distinct characteristics, and even two metals of the same name, such as stainless steels, may also have distinct characteristics. Significantly different metals are welded with each other to maximize the advantages produced by each metal while minimizing the disadvantages. Table 2 is showing different welding techniques for dissimilar metals based various parameters and applications in various industries. 
Table 2: Comparison of various Welding Techniques for Dissimilar Metals

\begin{tabular}{|c|c|c|c|c|c|c|}
\hline $\begin{array}{l}\text { S. } \\
\text { No }\end{array}$ & $\begin{array}{c}\text { Welding } \\
\text { Technique }\end{array}$ & Explanation & Advantages & Limitation & $\begin{array}{c}\text { Application in } \\
\text { Industry }\end{array}$ & $\begin{array}{l}\text { Used in } \\
\text { industries }\end{array}$ \\
\hline 1. & $\begin{array}{l}\text { Explosion } \\
\text { Welding }\end{array}$ & $\begin{array}{l}\text { It is a solid-state } \\
\text { (solid-stage) } \\
\text { method where } \\
\text { welding is } \\
\text { performed by } \\
\text { accelerating one } \\
\text { of the parts at } \\
\text { exceptionally high } \\
\text { speed using } \\
\text { chemical } \\
\text { explosives. }\end{array}$ & $\begin{array}{l}\text { (i). Simple process. } \\
\text { (ii). It is possible } \\
\text { to link enormous } \\
\text { surfaces. } \\
\text { (iii). On thermo- } \\
\text { treated metals, } \\
\text { welds can be } \\
\text { developed without } \\
\text { influencing their } \\
\text { nanostructures. } \\
\text { (iv). A wide range } \\
\text { of widths can be } \\
\text { clad together } \\
\text { unpredictably. }\end{array}$ & $\begin{array}{l}\text { (i). Brittle } \\
\text { materials cannot } \\
\text { be processed. } \\
\text { (ii). Thickness } \\
\text { of flyer plate is } \\
\text { limited. } \\
\text { (iii). Safety and } \\
\text { security aspects } \\
\text { of storage and } \\
\text { using } \\
\text { explosives are } \\
\text { difficult. } \\
\text { (iv). Area } \\
\text { should be } \\
\text { cleaned and } \\
\text { sound grounded } \\
\text { for explosion. }\end{array}$ & $\begin{array}{l}\text { (i). Used in } \\
\text { feed water } \\
\text { heater tubes. } \\
\text { (ii). Used to } \\
\text { weld } \\
\text { cylindrical and } \\
\text { concentric } \\
\text { equipments in } \\
\text { the industries. } \\
\text { (iii). Used to } \\
\text { weld light } \\
\text { weight metal } \\
\text { sheets. } \\
\text { (iv). Used to } \\
\text { weld heat } \\
\text { exchanger with } \\
\text { clad tubes in } \\
\text { industries. }\end{array}$ & $\begin{array}{l}\text { (i). CIS } \\
\text { CO.PVT LTD, } \\
\text { Gwangju. } \\
\text { (ii) Royal } \\
\text { Castor } \\
\text { Products } \\
\text { Limited. }\end{array}$ \\
\hline 2. & $\begin{array}{l}\text { Ultrasonic } \\
\text { Welding }\end{array}$ & $\begin{array}{l}\text { It is an industrial } \\
\text { method by which } \\
\text { large-frequency } \\
\text { high frequency } \\
\text { electromagnetic } \\
\text { frequencies are } \\
\text { applied globally to } \\
\text { work pieces held } \\
\text { together under } \\
\text { stress to produce } \\
\text { rigid-state } \\
\text { welding. }\end{array}$ & $\begin{array}{l}\text { (i). This welding } \\
\text { can be quick and } \\
\text { easy to optimize. } \\
\text { (ii). This generates } \\
\text { high-resistance } \\
\text { bond without } \\
\text { additional heat } \\
\text { being applied. } \\
\text { (iii). This is } \\
\text { smooth and after } \\
\text { welding offers a } \\
\text { nice surface finish. } \\
\text { This welding can } \\
\text { be quickly and } \\
\text { easily mechanized. } \\
\text { (iv). This creates a } \\
\text { high power joint } \\
\text { without internal } \\
\text { application. }\end{array}$ & $\begin{array}{l}\text { (i). The method } \\
\text { of ultrasonic } \\
\text { welding is } \\
\text { limited to the } \\
\text { lap joints. } \\
\text { (ii). Joint width } \\
\text { is limited. } \\
\text { (iii). High } \\
\text { intensity } \\
\text { challenge } \\
\text { (iv). High } \\
\text { hardness } \\
\text { materials. } \\
\text { (v). The topic of } \\
\text { the material } \\
\text { modification } \\
\text { under the } \\
\text { machining, it } \\
\text { can generate } \\
\text { noticeable noise } \\
\text { from part } \\
\text { friction and } \\
\text { many } \\
\text { technicians are } \\
\text { uncomfortable } \\
\text { with the } \\
\text { method. }\end{array}$ & $\begin{array}{l}\text { (i). Used in } \\
\text { nuclear } \\
\text { industry for } \\
\text { fabrication of } \\
\text { nuclear } \\
\text { components. } \\
\text { (ii). Key, head } \\
\text { lamp parts, } \\
\text { buttons and } \\
\text { switches are } \\
\text { welding in } \\
\text { automobile } \\
\text { industries. } \\
\text { (iii). Used in } \\
\text { electrical } \\
\text { industries. } \\
\text { (iv). Used in } \\
\text { medical } \\
\text { industry for } \\
\text { accomplishing } \\
\text { clean process } \\
\text { parts. }\end{array}$ & $\begin{array}{l}\text { (i). Shin Hung } \\
\text { Ind. Co. Ltd. } \\
\text { (ii). M K } \\
\text { Precision } \\
\text { Metal Parts } \\
\text { Private Ltd. } \\
\text { (iii). Bhawani } \\
\text { Krupa } \\
\text { Enterprises. } \\
\text { (iv) Kurz India } \\
\text { private limited. }\end{array}$ \\
\hline 3. & $\begin{array}{c}\text { Friction Stir } \\
\text { Welding(FSW) }\end{array}$ & $\begin{array}{l}\text { is a solid-state } \\
\text { joining process } \\
\text { using a un- } \\
\text { consumable tool } \\
\text { to join two } \\
\text { masterpieces } \\
\text { experiencing } \\
\text { without melting } \\
\text { the material of the } \\
\text { work piece. It is }\end{array}$ & $\begin{array}{l}\text { (i). Good } \\
\text { mechanical } \\
\text { properties in the } \\
\text { as-welded } \\
\text { condition. } \\
\text { (ii). Enhanced } \\
\text { comfort owing to } \\
\text { the lack of noxious } \\
\text { fumes or molten } \\
\text { material splatter. }\end{array}$ & $\begin{array}{l}\text { (i). Exit hole } \\
\text { left when tool is } \\
\text { withdrawn. } \\
\text { (ii). Huge down } \\
\text { efforts needed } \\
\text { to keep the } \\
\text { plates together } \\
\text { with heavy-duty } \\
\text { pinching. } \\
\text { (iii). Less }\end{array}$ & $\begin{array}{l}\text { (i). Used for } \\
\text { welding tubes } \\
\text { and shafts in } \\
\text { industries. } \\
\text { (ii). Used for } \\
\text { welding gears } \\
\text { axles etc } \\
\text { (iii). Used in } \\
\text { aerospace } \\
\text { industries. }\end{array}$ & $\begin{array}{l}\text { (i). Gautam } \\
\text { Steels } \\
\text { Industries. } \\
\text { (ii). ER Auto } \\
\text { Private } \\
\text { Limited. } \\
\text { (iii). Hira } \\
\text { Group of } \\
\text { Industries. } \\
\text { (iv)Woolworth }\end{array}$ \\
\hline
\end{tabular}




\begin{tabular}{|c|c|c|c|c|c|c|}
\hline & & $\begin{array}{l}\text { used mainly for } \\
\text { forged or extruded } \\
\text { aluminum and } \\
\text { especially for } \\
\text { constructions that } \\
\text { require very high } \\
\text { welding power. }\end{array}$ & $\begin{array}{l}\text { (iii). No } \\
\text { consumables (no } \\
\text { filler gas shield). } \\
\text { (iv). Process is } \\
\text { easily automated. } \\
\text { (v). Lower set up } \\
\text { costs. }\end{array}$ & $\begin{array}{l}\text { versatile than } \\
\text { conventional } \\
\text { and arc } \\
\text { procedures } \\
\text { (difficulty with } \\
\text { differences in } \\
\text { density and } \\
\text { non-linear } \\
\text { welding). } \\
\text { (iv). Often the } \\
\text { drift speed is } \\
\text { weaker than } \\
\text { some methods } \\
\text { for fusion } \\
\text { welding, though } \\
\text { this can be } \\
\text { offset if less } \\
\text { welding moves } \\
\text { are needed. }\end{array}$ & $\begin{array}{l}\text { (iv). Used in } \\
\text { marine and oil } \\
\text { industries. } \\
\text { (v). This } \\
\text { welding is } \\
\text { used to replace } \\
\text { forging or } \\
\text { casting } \\
\text { assembly. }\end{array}$ & India Limited. \\
\hline 4. & Arc Welding & $\begin{array}{l}\text { It is a welding } \\
\text { method used to } \\
\text { connect metal to } \\
\text { metal by using } \\
\text { electricity to } \\
\text { generate sufficient } \\
\text { heat to melt metal, } \\
\text { and heated metals } \\
\text { when cool result } \\
\text { in metal bonding. }\end{array}$ & $\begin{array}{l}\text { (i). Produces less } \\
\text { destruction of the } \\
\text { material. } \\
\text { (ii). Less } \\
\text { expensive. } \\
\text { (iii). Welding is } \\
\text { accomplished very } \\
\text { smoothly. } \\
\text { (iv). This welding } \\
\text { is much resistant to } \\
\text { corrosion. } \\
\text { (v). less pollution } \\
\text { occurred from this } \\
\text { welding process. }\end{array}$ & $\begin{array}{l}\text { (i). } \\
\text { Mechanization } \\
\text { is difficult due } \\
\text { to brittle flux } \\
\text { coating. } \\
\text { (ii). Slow } \\
\text { processes than } \\
\text { MIG. } \\
\text { (iii). Defect } \\
\text { occurs at the } \\
\text { place of } \\
\text { restarting of } \\
\text { welding again. } \\
\text { (iv). Weld } \\
\text { toughness } \\
\text { occurs very } \\
\text { low. }\end{array}$ & $\begin{array}{l}\text { (i). Used to } \\
\text { weld large } \\
\text { constructions } \\
\text { inside and } \\
\text { outside the } \\
\text { industries. } \\
\text { (ii). Large and } \\
\text { highly } \\
\text { complicated } \\
\text { mechanical } \\
\text { machineries } \\
\text { are welded } \\
\text { using this } \\
\text { process. } \\
\text { (iii). This } \\
\text { welding is } \\
\text { used I } \\
\text { shipbuilding } \\
\text { industry. }\end{array}$ & $\begin{array}{l}\text { (i). Precicraft } \\
\text { Components } \\
\text { India Limited. } \\
\text { (ii). Krystal } \\
\text { Steels } \\
\text { Manufacturing } \\
\text { Private } \\
\text { Limited. } \\
\text { (iii). Balasore } \\
\text { Alloys } \\
\text { Limited. } \\
\text { (iv). } \\
\text { Readymade } \\
\text { Steel India } \\
\text { Limitd. }\end{array}$ \\
\hline 5. & $\begin{array}{l}\text { Diffusion } \\
\text { Welding. }\end{array}$ & $\begin{array}{l}\text { It is a solid state } \\
\text { welding technique } \\
\text { used in metal } \\
\text { working capable } \\
\text { of joining similar } \\
\text { and dissimilar } \\
\text { metals. It operates } \\
\text { on the principal of } \\
\text { hard state } \\
\text { diffusion where in } \\
\text { the atom of two } \\
\text { solids metallic } \\
\text { surfaces } \\
\text { intersperse } \\
\text { themselves over } \\
\text { time. }\end{array}$ & $\begin{array}{l}\text { (i). Low running } \\
\text { cost. } \\
\text { (ii). Both similar } \\
\text { and dissimilar } \\
\text { metals can be } \\
\text { joined more easily. } \\
\text { (iii). Filler material } \\
\text { is not used in this } \\
\text { welding process. } \\
\text { (iv). More and } \\
\text { more complex } \\
\text { shapes can be } \\
\text { welded easily. }\end{array}$ & $\begin{array}{l}\text { (i). Low } \\
\text { productivity } \\
\text { process. } \\
\text { (ii). Time } \\
\text { consuming } \\
\text { welding } \\
\text { process. } \\
\text { (iii). High initial } \\
\text { investment for } \\
\text { the welding } \\
\text { process. } \\
\text { (iv). It is more } \\
\text { difficult to } \\
\text { prepare surface. } \\
\text { (v). Depends on } \\
\text { the welding } \\
\text { parameters. }\end{array}$ & $\begin{array}{l}\text { (i). Aerospace } \\
\text { industry. } \\
\text { (ii). Nuclear } \\
\text { industry. } \\
\text { (iii). Used to } \\
\text { weld copper } \\
\text { with aluminum } \\
\text { as well as } \\
\text { titanium metal } \\
\text { which are hard } \\
\text { to weld easily. } \\
\text { (iv). Used to } \\
\text { weld titanium, } \\
\text { beryllium, } \\
\text { zirconium, } \\
\text { which are } \\
\text { difficult to } \\
\text { weld? }\end{array}$ & $\begin{array}{l}\text { (i). AM } \\
\text { Engineering } \\
\text { Services. } \\
\text { (ii). Universal } \\
\text { Engineering \& } \\
\text { Metal } \\
\text { Corporation. } \\
\text { (iii). Global } \\
\text { Impex. } \\
\text { (iv). Binju } \\
\text { Metals \& } \\
\text { Alloys Private } \\
\text { Limited. }\end{array}$ \\
\hline 6. & Cold Welding & $\begin{array}{l}\text { It is a method of } \\
\text { hard state welding } \\
\text { in which the }\end{array}$ & $\begin{array}{l}\text { (i). Heating is not } \\
\text { required in this } \\
\text { welding process. }\end{array}$ & $\begin{array}{l}\text { (i). For } \\
\text { deformation } \\
\text { higher forces }\end{array}$ & $\begin{array}{l}\text { (i). This } \\
\text { welding is } \\
\text { used in }\end{array}$ & $\begin{array}{l}\text { (i). Federal } \\
\text { Mogul } \\
\text { Corporation. }\end{array}$ \\
\hline
\end{tabular}




\begin{tabular}{|c|c|c|c|c|c|c|}
\hline & & $\begin{array}{l}\text { merging takes } \\
\text { place at the border } \\
\text { of the two } \\
\text { components to be } \\
\text { fastened without } \\
\text { fusion. In } \\
\text { comparison with } \\
\text { the other methods } \\
\text { of fusion welding } \\
\text { there is no fluid } \\
\text { phase in the joint. }\end{array}$ & $\begin{array}{l}\text { (ii). As compared } \\
\text { to other processes } \\
\text { better surface } \\
\text { finished is } \\
\text { obtained. } \\
\text { (iii). Through this } \\
\text { process better } \\
\text { reproducibility and } \\
\text { interchangeability } \\
\text { is obtained. } \\
\text { (iv). Improved } \\
\text { strength is } \\
\text { obtained. }\end{array}$ & $\begin{array}{l}\text { are required. } \\
\text { (ii). Less } \\
\text { ductility is } \\
\text { available. } \\
\text { (iii). This } \\
\text { welding may } \\
\text { produce } \\
\text { undesirable } \\
\text { stresses. } \\
\text { (iv). This } \\
\text { welding process } \\
\text { requires } \\
\text { intermediate } \\
\text { anneals. }\end{array}$ & $\begin{array}{l}\text { industries form } \\
\text { pinch press, } \\
\text { punch die etc } \\
\text { (ii). Wires are } \\
\text { welded by this } \\
\text { welding when } \\
\text { broke in } \\
\text { operations. } \\
\text { (iii). Cu, Al } \\
\text { and various } \\
\text { others metals } \\
\text { and its alloys } \\
\text { are welded by } \\
\text { this process. } \\
\text { (iv). This } \\
\text { welding is } \\
\text { used to weld } \\
\text { dissimilar } \\
\text { metals. }\end{array}$ & $\begin{array}{l}\text { (ii). Gee Cee } \\
\text { Group of } \\
\text { Industries. } \\
\text { (iii). } \\
\text { DONGSUH } \\
\text { industry } \\
\text { CO.Ltd. }\end{array}$ \\
\hline 7. & $\begin{array}{l}\text { Electron Beam } \\
\text { Welding(EBW) }\end{array}$ & $\begin{array}{l}\text { It is a hybrid } \\
\text { welding method in } \\
\text { which a high } \\
\text { volume photon } \\
\text { beam is applied } \\
\text { for joining two } \\
\text { metals. As the } \\
\text { atoms,,, kinetic } \\
\text { power is } \\
\text { converted into } \\
\text { heat upon effect, } \\
\text { the work piece } \\
\text { floats together. It } \\
\text { is often performed } \\
\text { under } \\
\text { circumstances of } \\
\text { closed systems to } \\
\text { prevent the } \\
\text { electron beam } \\
\text { from dissipating. }\end{array}$ & $\begin{array}{l}\text { (i). Better } \\
\text { repeatability and } \\
\text { accuracy. } \\
\text { (ii). Dissimilar } \\
\text { metals can be } \\
\text { joined easily. } \\
\text { (iii). Filler } \\
\text { materials are not } \\
\text { used in this } \\
\text { process. } \\
\text { (iv). Less } \\
\text { expensive and } \\
\text { hence cost saving. } \\
\text { (v). As compared } \\
\text { to the other } \\
\text { welding } \\
\text { operations, better } \\
\text { welding speed. }\end{array}$ & $\begin{array}{l}\text { (i). High initial } \\
\text { setup cost. } \\
\text { (ii) Other } \\
\text { disadvantage is } \\
\text { size limitation. } \\
\text { (iii). From this } \\
\text { process high x } \\
\text { rays radiation } \\
\text { occur which are } \\
\text { harmful. } \\
\text { (iv). Expert } \\
\text { operators and } \\
\text { skilled labor are } \\
\text { required due to } \\
\text { complex } \\
\text { equipments and } \\
\text { its welding. }\end{array}$ & $\begin{array}{l}\text { (i). Used in } \\
\text { aerospace } \\
\text { industry. } \\
\text { (ii). This } \\
\text { welding is } \\
\text { used in } \\
\text { industries } \\
\text { where high } \\
\text { power } \\
\text { generation is } \\
\text { produced. } \\
\text { (iii). Used in } \\
\text { defense } \\
\text { services } \\
\text { (iv). Used } \\
\text { frequently in } \\
\text { automotive } \\
\text { industry. } \\
\text { (v). Used in oil } \\
\text { and gas } \\
\text { industry for } \\
\text { major welding } \\
\text { operations. }\end{array}$ & $\begin{array}{l}\text { (i). Precious } \\
\text { Industries. } \\
\text { (ii) Gravity } \\
\text { Cast Private } \\
\text { Limited. } \\
\text { (iii). Bilpower } \\
\text { Limited. } \\
\text { (iv)Ally } \\
\text { International } \\
\text { Company. } \\
\text { (iv). Gemus } \\
\text { Engineering } \\
\text { Limited. } \\
\text { (v). ACMI } \\
\text { Industries. }\end{array}$ \\
\hline
\end{tabular}

\subsection{Comparison of Welding Techniques}

This section of paper provides a comparison between various welding techniques for different metals. The comparison is based on the web search done by the people for particular welding techniques all over the world. Through these researchers able to conclude that which technique is most popular among the people? The figures given below illustrate the comparison between the techniques:

Figure 1 shows a graph that depicts friction stir welding is widely used techniques for joining dissimilar metals than ultrasonic and explosion welding. The above graph is obtained on the basis of the web searches all over the world. The friction is popular because of its lower setup cost.

Through the graph shown in Figure 2 we can conclude that cold welding and diffusion welding for joining dissimilar metals are less used in industries. But the arc welding is largely used in industries as its functioning is easy and the procedure 
to carry out the arc welding is systematic and easy to implement.

Figure 3 shows depicts that friction welding is not better than arc welding as arc welding implementation is easy and less expensive mechanism of carrying out the welding. It also reduces the chances of corrosion of metals i.e. the main reason it popular among other welding techniques.

Figure 4 shows this graph it is clear that arc welding is mostly used by the industries for welding of dissimilar welding and the least used welding id cold welding as its area of application is limited.

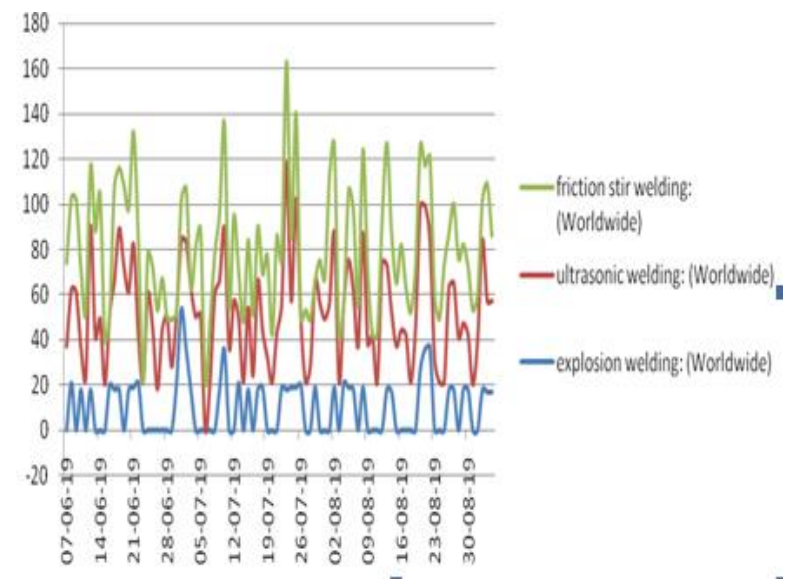

Figure 1: Comparison of Friction, Ultrasonic, Explosion Welding.

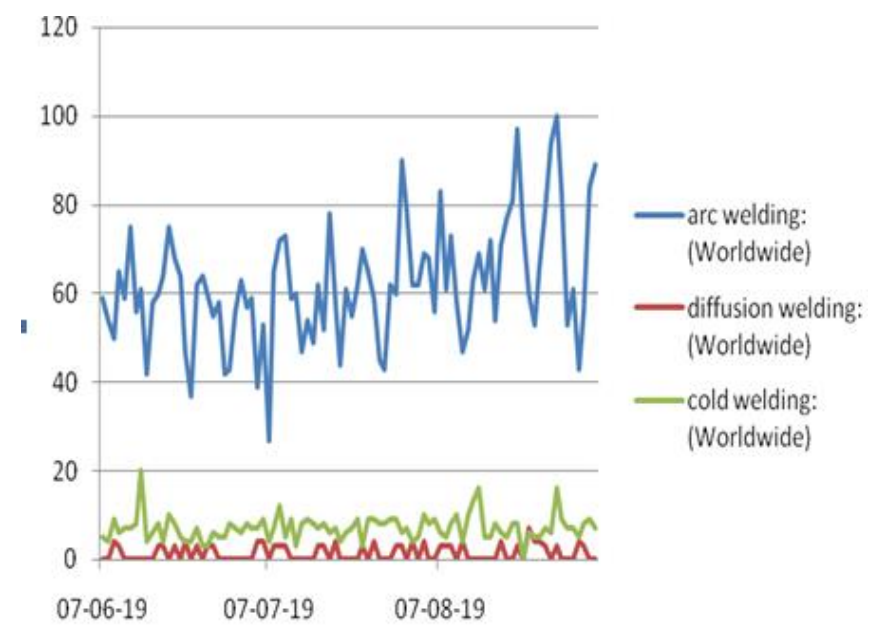

Figure 2: Comparison of Arc, Diffusion, and Cold welding. 


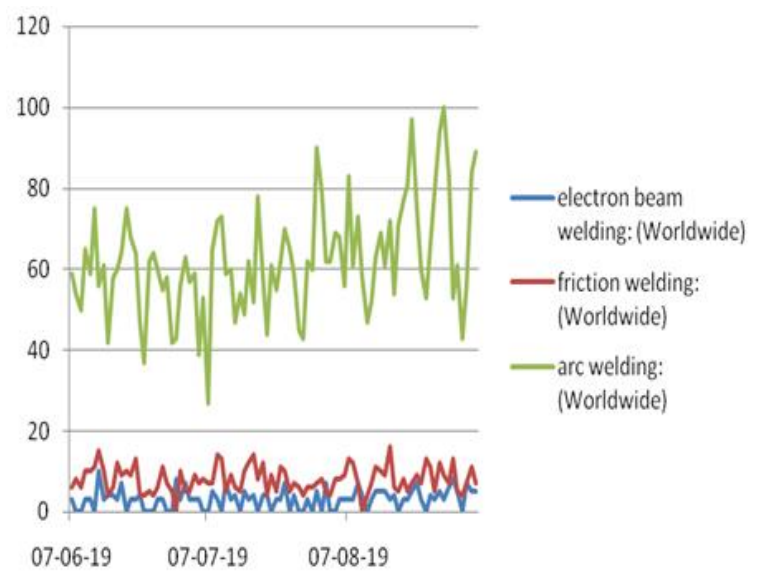

Figure 3: Comparison of Electron beam, Friction, Arc Welding.

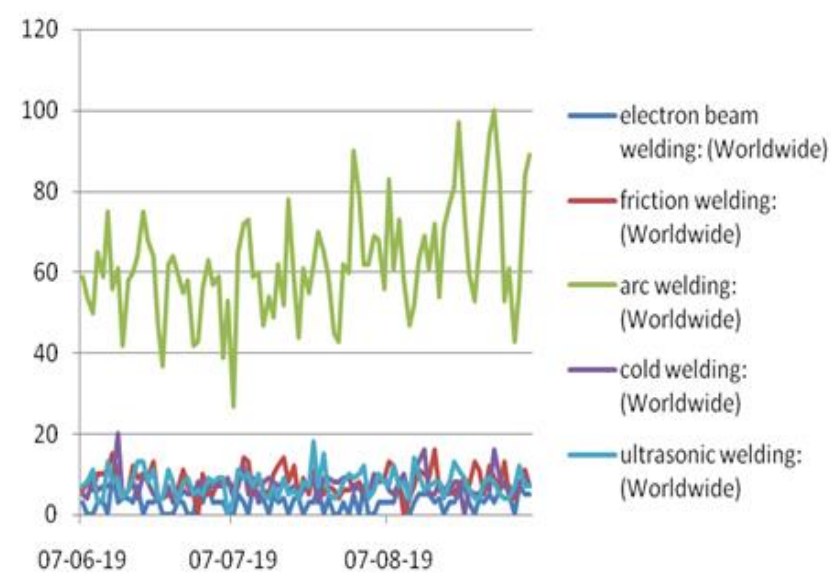

Figure 4: Comparison of Electron beam, Arc, Ultrasonic, Cold, Friction Welding.

\section{CONCLUSIONS}

Through this paper authors investigates the various welding techniques that are used by industries all the world for joining of different metals. The features, advantages, disadvantages, limitations, applications and industries in which these welding techniques are used. By investigation of this paper, the Arc Welding is come out to most talked and used techniques for welding of dissimilar metals. The cold welding techniques is least talked and used techniques among all the techniques of dissimilar metal welding based on various grounds.

\section{FUTURE SCOPE}

For future work, the researchers can point out some other welding processes that are widely used in various industries all over the world. The researchers can propose the welding for various dissimilar materials not only metals such as polymer to metals welding.

\section{ACKNOWLEDGMENTS}

We would like to express our special gratitude to God for giving us knowledge. We would also like to thank Mr. Ravindra Kumar (Prof.) for their valuable support and guidance throughput the work. 


\section{REFERENCES}

1. Paul Kah, Madan Shrestha Jukka Martikainen, “Trends in Joining Dissimilar Metals by Welding”, Applied Mechanics and Materials Vol. 440 (2014) pp 269-276 Online available since 2013/Oct/31 @ (2014) Trans Tech Publications, Switzerland doi:10.4028/www.scientific.net/AMM.440.269.

2. Paul Kah, Raimo Suoranta, Jukka Martikainen, Carl Magnus, “Techniques For Joining Dissimilar Materials: Metals And Polymer”, Rev. Adv. Master. SCI. 36 (2014) 152-164, 2014 Advanced Study Center Co. Ltd.

3. Mumin SAHIN, Kaan OZEL, “Cold Pressure Welding And Its Application To Aluminium Sheets”, 22. -24.5.2007, Hradec nad Moravicí.

4. FRANK BALLE, “Ultrasonic Welding”, JOM, Vol. 64, No. 3, 2012 DOI: 10.1007/s11837-012-0261-0 2012 TMS.

5. B. Mvola, P. Kah and J. Martikainen, ” Dissimilar Ferrous Metal Welding Using Advanced Gas Metal Arc Welding Processes”, Rev.Adv.Master.Sci.38(2014) 125-137, 2014 Advanced Study Center Co. Ltd.

6. Belinga Mvola, Paul Kah and Jukka Martikainen, "Welding of dissimilar non-ferrous metals by GMAW processes", Mvola et al. International Journal of Mechanical and Materials Engineering 2014, 9:21 http://www.springer.com/40712/content/9/1/21.

7. Liming Liu, Daxin Ren and Fei Liu, “A Review of Dissimilar Welding Techniques for Magnesium Alloys to Aluminum Alloys”, Materials 2014, 7, 3735-3757; doi: 10.3390/ma7053735, ISSN 19961944.

8. MEDGYESI, T[iberiu]; POPESCU, M[ihaela] \& OPRIS, C[armen], "Difficulties Encountered In Performing Dissimilar Joints On Sheets", Annals of DAAAM for 2011 \& Proceedings of the 22nd International DAAAM Symposium, Volume 22, No. 1, ISSN 1726-967 ISBN 978-3-901509-83-4, Editor B. Katalinic, Published by DAAAM International, Vienna, Austria, EU, 2011.

9. RAO, G. ANANDA, G. CHANDRA MOHANA REDDY, and G. SUNNY RAJ KUMAR. "MULTI RESPONSE OBJECTIVE OPTIMIZATION OF FRICTION STIR WELDING PARAMETERS OF DISSIMILAR METALS OF AA 6061 ALUMINUMAND IS319 BRASS JOINING THROUGH TAGUCHI'S METHOD. "International Journal of Mechanical and Production Engineering Research and Development (IJMPERD) 8.1 (2018):429436.

10. YUN, KYYOUL, et al. "NEW FABRICATION METHOD SUGGESTION OF THE MOTOR CORE WITH DISSIMILAR METAL BONDING METHOD. " IASET: International Journal of Metallurgical, Materials and Chemical Engineering (IASET: IJMMCE) 1.3 (2016): 18.

11. El-Shennawy, M., Adel A. Omar, and M. Ayad. "Similar and Dissimilar Friction Stir Welding of AA7075" International Journal of Mechanical Engineering (IJME) 3.4 (2014): 6986.

12. Shubhavardhan, R. N. "Microstructure and Tensile Strength of Friction Stir Welding of Al-Cu." International Journal of Mechanical and Production Engineering Research and Development (IJMPERD) 5.2 (2015): 4150.

13. REDDY, M. YADI, and K. RAJANIKANTH "AN EXPERIMENTAL INVESTIGATION AND PROCESS PARAMETERS OPTIMIZATION OF FRICTION STIR WELDED DISSIMILAR ALLOYS. " International Journal of Mechanical and Production Engineering Research and Development (IJMPERD) 9.4 (2019):919926. 
